East and South-East areas, as pelagic sediments. This typical Chalk consists of 90-9S per cent. of carbonate of lime; the proportion of silica is, in geveral, insignificant, save in the I. labiatus zone, which shows an analysis of 14 per cent.; the argillaceous materials do not, as a rule, exceed 1 per cent. The Senonian chalks, which are now poor in micro-organisms, were probably originally foraminiferal in character. The changes which have taken place in the original sediments tend to produce a crystalline calcite in which all traces of organization have disappeared.

In the two concluding chapters of the work a comparison of the Chalk with the recent Globigerina ooze is made, and the conditions of the Cretaceous sea considered. The author's opinion that the depth of this sea at the time of the greatest depression, when the Belemnitella chalk was forming, did not exceed 150 fathoms, certainly does not err on the side of excess.

The work is illustrated by some excellent phototypes of sections of different kinds of Gaize and beautifully executed lithographic plates of Radiolaria, enlarged sections of Chalk, glauconite, and other minerals.

G. J. Hinde.

II.-The Geology of the Colntry around Bournemouth. By Clement Reid, F.L.S., F.G.S. Memoirs of the Geological Survey. 8vo; pp. iv, 12, with 14 illustrations. (London, 1898. Price 4d.)

TN our July number we noticed the recently published Geology 1 of Bognor issued by the Geological Survey; we have now to announce a companion memoir on Bournemouth, in explanation of the New Series Map Sheet 329. The Director-General, in bis preface, briefly refers to previous geological works, while the author gives a concise account of the geological features. Reference is especially made to the labours of Mr. J. Starkie Gardner, who has done more than any other geologist to make known the lifehistory of the Eocene strata on the Hampshire coast. Figures are given of a number of the characteristic Barton fossils, and it is interesting to observe that most of the species were illustrated more than 130 years ago by Brander. The strata noted are the Upper Chalk, the entire Eocene series, the Headon Beds, and various Pleistocene and Recent deposits.

\title{
COREFSPONDEINCF.
}

\section{THE SUBMERGED PLATFORM OF WESTERN EUROPE.}

Sir,-Mr. Jukes-Browne's letter in the September number of the Geologrcal Magazine must not be left without some reply, notwithstanding that I have since dealt with its subject in some detail at the Bristol meeting of the British Association. The facts and 
arguments I there brought forward may possibly modify his views on the question of the submerged physical features of the North Atlantic.

Mr. Jukes-Browne objects to the term 'escarpment' as applied to the great declivity along which the Anglo-Continental platform terminates, both on the ground of its great lateral extension and because of its elevation. These are only matters of degree. The question is really one of form, and to my mind on the ground of form the term is correct; the declivity has a terraced upper surface, has a descent, sometimes almost precipitous, and falls off in a slope, sometimes gentle, at its base into the abyssal plain. Putting geological structure aside, which in this case is inadmissible, this is the form of the escarpments of the Oolite, New Red Sandstone, Millstone Grit, and older rocks in this country and of parts of Europe. I do not know on what ground the writer objects to the range of the Nummulite Limestone along the south of the Nile Delta being called 'technically' an escarpment. Perhaps he has not himself seen its eastern extremity of Jebel Attaka, where it overlooks the Red Sea, and is one of the grandest escarpments I have ever seen as viewed from Suez.

The writer objects to the statement that I have expressed regarding these submerged physical features having been formed under terrestrial conditions; but he omits to mention the one crucial test of their terrestrial formation, namely, the river channels sometimes traceable up to or in proximity to the existing rivers draining the adjoining lands. He was probably not aware when he wrote his letter to what extent I have been able to determine these channels or cañons along the whole coastline from the English Channel to the Tagus. Such channels, with well-defined walls and ever deepening floors as we proceed outwards, cross the continental platform and the great escarpment opening out on the floor of the ocean at depths of 1,000 to 1,500 fathoms. One of these, commencing at the embouchure of the Adour, is so continuous and remarkable that Élisée Reclus, not recognizing its true nature, contents himself with exclaiming "What shall we say of that deep gulf?" etc., and leaves the question for answer to the future! I quite admit that in the absence of this succession of great channels, each one of which becomes accumulating evidence of its true nature, the question of the origin of the escarpment might have remained problematical, and it might have been supposed, for instance, that it represented the edge of a great depression of the ocean bed. But the river channels, which we cannot conceive could have been formed beneath the ocean itself, are, as it seems to me, the unquestionable proof of subaerial origin, both of themselves and of the physical features with which they are connected. Let Mr. Jukes-Browne procure the Admiralty Charts for himself and trace out the isobathio contours by means of the soundings, and then state his conclusions regarding the views which have been impressed on my own mind.

As regards the geological periods during which the features were elaborated, I cannot here discuss the question. I admit that I have 
not up till now sufficiently attempted this part of the subject; I hope to do so on a future occasion. Meanwhile the elucidation of the features themselves, the preparation of cross-sections of the submerged cañons, escarpments, and other phenomera, have occupied so much of my time and have been of such absorbing interest that I have thought it better to leave the question of geological age and mode of formation to the future. This part of the subject I hope to deal with when the paper, now nearly written, shall have been brought before one of our scientific societies during the ensuing session.

Edward Hull.

\section{OBITUARY.}

\section{PROFESSOR des CloizeauX, Memb. Inst. de France.}

BonN 1817 .

DIED MAY, 1897.

Monsieur Alfred L. O. Des Cloizeaux, the eminent French mineralogist, was a Membre de l'Institut de France and a Foreign Member of the Royal Society. He was Professor of Mineralogy in the Museum of Natural History, Paris, and was elected a Foreign Member of the Geological Society of London in 1884. Sir Warington Smyth, when receiving the Wollaston Medal of that Society on behalf of M. des Cloizeaux, said: "It is more especially in the wide and successful application of Wollaston's invention of the 'Reflecting Goniometer' that Des Cloizeaux has attained so deserved an eminence, following closely upon the steps of Professor Miller, to whom, in his admirable "Manuel," he pays so high a compliment." Des Cloizeanx's first paper was published 54 years ago, and was the beginning of a long series treating of the forms and optical characters of crystals. After being Professor of Mineralogy for eighteen years at the Ecole Normal Superieure, he was appointed to the charge of the minerals at the Musée d'Histoire Naturelle, in which office he remained until he reached the limit of age prescribed by the rules of the French Civil Service. His fame rests upon the thoroughness and accuracy of his systematic investigation of the crystals of minerals, more especially as regards their optical properties. The results are incorporated in his "Manuel de Minéralogie," a standard book of reference. Professor des Cloizeaux died, in the 80 th year of his age, in May, 1897. Monsieur Damour, his friend and co-worker for fifty-three years, writes: "In everything he applied himself to the spread of all that he deemed useful, just, and wise. All those who knew him honoured him and loved him. His name as a savant remains in the history of Mineralogy; he there occupies the most honourable place among the founders of this science, and among those who have contributed to its progress and advancement." 